\title{
NARODZINY TERAPII FILOZOFICZNEJ Z DUCHA ANTYKU. W KIERUNKU STAWANIA SIĘ OSOBĄ
}

\begin{abstract}
Streszczenie. Autor wylicza problemy, którymi zajmuje się terapia filozoficzna i podejmuje próbę podania jej definicji. W tekście znajdziemy odwołania do psychologii homeryckiej, współczesnych nurtów terapeutycznych oraz przykładów zastosowania terapii filozoficznej (zapisy obserwacji osób po odbyciu indywidualnej sesji terapii filozoficznej lub pracy grupowej). W artykule ukazany został związek terapii filozoficznej ze starożytnym pojmowaniem filozofii (antyczne ćwiczenia duchowe). Główną osią, wokół której prowadzone są rozważania jest zastosowanie terapii filozoficznej w procesie stawania się osobą.
\end{abstract}

Słowa kluczowe: stawanie się osobą, terapia filozoficzna, filozofia praktyczna, psychologia homerycka, ćwiczenia duchowe, uświadomione mówienie, uobecnienie siebie, dusza.

1. Założenia wstępne. 2. Obcowanie z duszą. Uobecnienie. 3. Stawanie się osobą. 4. Aspekty filozoficzne. 5. Terapia filozoficzna i podejścia alternatywne. 6. Cel terapii filozoficznej. 7. Stawanie się terapeutą filozoficznym. 8. Próba definicji.

W poprzednich pracach zajmowałem się interpretacją metody majeutycznej Sokratesa w duchu psychologii homeryckiej ${ }^{1}$ (sztuką uświadomionego mówienia ${ }^{2}$ ). Wykorzystanie tej, wydawałoby się, „naiwnej psychologii” dało nad wyraz ciekawe rezultaty w pracy z klientami. W celu ukucia definicji terapii filozoficznej, chciałbym

1 Psychologię homerycką z zapomnienia przywrócił nam Tadeusz Kobierzycki, tłumacząc na język polski pracę wybitnego polskiego badacza świata antycznego i filologa, Tadeusza Zielińskiego (T. Zieliński, Psychologia homerycka, tłum. z ros. T. Kobierzycki, Heksis (1922/1999) 1-2, 3-33). Zob. też: T. Kobierzycki, Miejsce i rola uczuć w opisie duszy cielesnej i niecielesnej u Homera, Heksis (2010)4, 3-15).

2 T. Femiak, O uobecnieniu duszy, Sokratesie psychagogu i sztuce uświadomionego mówienia, Studia Philosophiae Christianae 54(2018)3, 85-110; tenże, Narodziny głosu sztuka uświadomionego mówienia, jako narzędzie rozpoznawania głosu, w: Psychologia narracyjna. Tożsamość, dialogowość, red. E. Dryll, A Cierpka, Enetheia, Warszawa 2011, 43-62. 
obecnie poddać refleksji efekty zastosowania uświadomionego mówienia oraz wybrane założenia teoretyczne, towarzyszące pracy filozofa terapeuty. Zbierając materiał niezbędny do podania interesującej nas definicji, zbliżymy się do głębszego zrozumienia tego, czym jest terapia filozoficzna w kontekście zabiegów mających na celu uruchomienie lub wsparcie procesu „stawania się osobą”. Niektóre z założeń leżących u podstaw terapii filozoficznej wprost odnoszą się do kondycji psychofizycznej człowieka, jego rozumienia samego siebie i własnej duchowości. W naszych rozważaniach oprzemy się na psychologii homeryckiej oraz antycznej filozofii i jej ćwiczeniach duchowych ${ }^{3}$.

\section{ZAŁOŻENIA WSTĘPNE}

Podstawowym założeniem terapii filozoficznej nawiązującej do praktyk filozofii starożytnej jest przyjęcie istnienia duszy ludzkiej, powiązanej z ciałem człowieka. W przyjętym nastawieniu terapeutycznym łączę (1) platońskie i (2) arystotelesowskie podejście do duszy ${ }^{4}$. U podstaw podejścia pierwszego leży badanie wyższych funkcji psychicznych związanych z procesami myślenia, samoświadomością i refleksją. Drugiego - badanie zjawisk biologicznych, rozwoju

3 Ujęte poniżej zagadnienia omawiane były w trakcie paneli dyskusyjnych podczas konferencji: Wokół Idei Doradztwa Filozoficznego V. Stawanie się osobą. Opole 12-13.12.2019. Podstawą praktyczną do napisania niniejszego tekstu są również doświadczenia zdobywane od roku 2002 w pracy indywidualnej i grupowej. Pierwsze kroki w stosowaniu w pracy z klientem psychologii homeryckiej oraz antycznych ćwiczeń duchowych, stawiane były wspólnie z psycholog Ewą Wojciechowską. Podczas pięciu lat współpracy łączyliśmy podejście psychologiczne z praktykami filozoficznymi. Gdy sytuacja na to pozwalała wprowadzaliśmy do pracy z klientami, pytania i ćwiczenia nawiązujące do antycznej psychagogiki. Obecnie prowadzę samodzielnie praktykę filozoficzną.

4 Na tym etapie rozważań nie uważam za konieczne poruszanie problematyki związanej z budową duszy, jej substancjalności, tego czy posiada autonomiczne części (np. rozumną, zapalczywą i pożądliwą), i tego jak się przejawia. 
i regeneracji ${ }^{5}$ W „psychologii” platońskiej na pierwszym planie lokowane były zagadnienia dostępne w intuicyjnym oglądzie i omawiane dyskursywnie. W praktyce terapeutycznej odpowiadają one m.in. wglądowi do świata wewnętrznego człowieka (aspekt introspekcyjny). W „psychologii” arystotelesowskiej badane były zjawiska życiowe (dostępne zmysłowo) poddawane następnie oglądowi intelektualnemu.

Jeżeli przyjmiemy, że dusza rozumna jest zasadą ciała, która pełni w nim funkcje regulatywne, to fakt jej "przyjęcia do ciała" (uobecnienie siebie) powinien wywoływać w nim harmonię i osiągnięcie stanu eutymii (równowagi miedzy sercem i umysłem). Antyczne ćwiczenia duchowe służyły temu właśnie celowi. We współczesnej praktyce terapeutycznej możemy ten proces określić jako zmierzający w stronę zharmonizowania przez klienta jego myślenia oraz świadomie przyjmowanych pragnień z obszarem nieuświadomionych dążeń, wyrażających się na poziomie ciała. Innymi słowy, sięgając do terminologii psychoanalitycznej, chodzi o uruchomienie „procesu pierwotnego”, tj. naturalnego dobrostanu człowieka, w którym funkcje poznawcze i emocjonalne są ze sobą w naturalny sposób powiązane.

\section{OBCOWANIE Z DUSZĄ. UOBECNIENIE}

Człowiek może nauczyć się obcowania z własną duszą, kierując odpowiednio swoją uwagą (prowadząc samoobserwację). Prowadzenie „nasłuchu” i „dostrajanie” się do wskazań duszy może stać się podstawą racjonalnych zmian w życiu. Nauczanie duchowości nie jest czymś „cudownym”. Może jednak doprowadzić do odmiany ludzkiego życia przez zastosowanie odpowiednich metod. Zazwyczaj procesy duchowe zachodzą poza uwagą człowieka. Ucząc się ich potrzebujemy przewodnika, podobnie jak to ma miejsce w innych dyscyplinach, do których przyuczamy się w trakcie życia. W starożytności

5 P. Lenartowicz, J. Koszteyn, Dusza. Platońskie i arystotelesowskie pojęcie duszy, https:// www.kul.pl/files/57/encyklopedia/lenartowicz_dusza.pdf (dostęp 21.03.2020). 
funkcję tę spełniał psychagog. ${ }^{6}$ W rzadkich przypadkach możliwe jest samodzielne wdrożenie się do tak rozumianych praktyk duchowych. Jak pokazują doświadczenia starożytnych i współczesnych terapeutów, zazwyczaj potrzebna jest jednak „inicjacja”, polegająca na wprowadzeniu człowieka do jego własnego świata wewnętrznego przez inną, bardziej doświadczoną osobę 7 . Podkreślić należy, że obcowanie $z$ własną duszą nie jest aktem jednorazowym. Zmieniając swoje życie człowiek może uruchomić proces rozwoju osobowego i sięgać do procesu źródłowego. Często jednak o tym zapomina jak to ujmował Platon - odwraca wzrok od nieprzyjemnych prawd o sobie, traktuje wytwory swojego umysłu za jedyną rzeczywistość $\mathrm{i}$,zapomina o prawdziwym bycie”.

To, co starożytni nazywali „odnowieniem kontaktu z duszą" i ,jej powtórnym osadzeniem w ciele”, nazywamy dalej „uobecnieniem” siebie. U osób skarżących się na „brak kontaktu z samym sobą”, "utratę sił witalnych i chęci do życia" i "poczucie wyobcowania" dokonanie wysiłku uobecnienia wywołuje poczucie ozdrowienia i „powrotu do siebie”, „odzyskania sił”, „pogodzenia się ze sobą”, „zharmonizowania”. Liczne opisy utraty kontaktu z własną duszą i jej przywołania znajdujemy w poematach Homera' ${ }^{9}$. Warto odnoto-

6 „Skoro w naturze mowy leży zdolność do prowadzenia dusz (psychagogia), to człowiek, który chce być mówcą musi koniecznie wiedzieć, ile form dusza posiada". Platon, Faidros, w: Dialogi, tłum. z gr. W. Witwicki, Kęty 1999, 2, 175 (171 C-171 D). Zob. też: tamże, 160 (161-161 B).

7 Taki stan podyktowany jest tym, że od dzieciństwa jesteśmy uczeni przekierowywania naszych zasobów poznawczych na zewnątrz. Dorosły człowiek prawie całkowicie pomija siebie wykonując większość czynności mechanicznie (nawykowo).

8 Określenia używane przez klientów.

9 U Homera spotykamy takie określenia jak: „stracił thymos”, „zostawił go thymos”, „uleciał jego thymos”, „zgubił thymos”. Thymos zachowuje analogię do duszy - psyche.

„Zaraz jej czarnym cieniem oczy noc powlekła,

Padła, z omdlałej ledwie dusza (psyche) nie uciekła. (...)

Gdy zmysły (thymos) odzyskała, płacze rozkwilona.

Nad mężem nieszczęśliwym nieszczęśliwa żona".

Homer, Iliada, tłum z gr. L. Siemieński, Kraków 2004, XXI.455-465, 247. 
wać, że model duchowości zawarty w psychologii Homeryckiej jest w pewnych obszarach zgodny z modelem duchowości znanym nam z tekstów Starego ${ }^{10}$ i Nowego Testamentu ${ }^{11}$.

Zarówno w czasach antycznych, jak i współcześnie człowiek jest „wybijany z siebie" przez niespodziewane zdarzenia, traumy i nawyki życia codziennego. Ma też szansę samodzielnego „przywołania swojej duszy" oraz możliwość zwrócenia się do innych o pomoc ${ }^{12}$. To, co Sokrates nazywa „odbieraniem porodów” było doprowadzeniem rozmówcy do świadomego przyjęcia pierwiastka duchowego i jego uobecnieniem w konkretnym przeżyciu poznawczym, traktowanym holistycznie (odczuwanym też na poziomie ciała). Dokonywało się to $\mathrm{w}$ procesie uświadomionego mówienia. Przyrównanie tej czynności do porodu jest bardzo trafne. Dla niektórych osób uobecnienie siebie jest głębokim przeżyciem duchowym, któremu towarzyszą

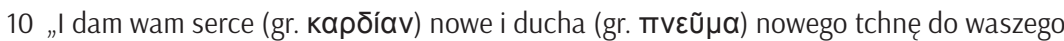
wnętrza" (Ezech. 36:26), Biblia tysiąclecia, http://www.biblia-internetowa.pl/Ezech/36/26. html (dostęp 21.2020). Zob. też Biblia Apologety, http://bibliaapologety.com/LXX/ Ez_36_26.htm (dostęp 21.2020).

„Jestem nieszczęśliwą kobietą, (...). Wylałam tylko duszę (gr. чuxńv) moją przed Panem" (1 Sam. 1:15), Biblia tysiąclecia, http://www.biblia-internetowa.pl/1Sam/1/15.html (dostęp 21.2020). Zob. też Biblia Apologety, http://bibliaapologety.com/LXX/1Krl_1_15. htm (dostęp 21.2020).

11 „Ojcowie, nie rozdrażniajcie waszych dzieci, aby nie traciły ducha (gr. athymōsin - tracić serce, być przygnębionym, ulec zniechęceniu)", (Kol 3:20-21), Biblia tysiąclecia (pobrano z: http://www.biblia-internetowa.pl/Kol/3/21.html (dostęp 21.2020). Zob. też Biblia Oblubiennica (pobrano z: https://biblia.oblubienica.eu/interlinearny/index/book/12/ chapter/3/verse/21/param/1/version/TR (dostęp 21.2020).

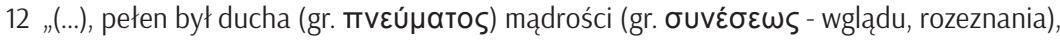
gdyż Mojżesz włożył na niego ręce", (5 Moj. 34:9), Biblia tysiąclecia (pobrano z: http:// www.biblia-internetowa.pl/5Moj/34/9.html (dostęp 21.2020). Zob. też Biblia Apologety (pobrano z: http://bibliaapologety.com/LXX/Pwt_34_9.htm (dostęp 21.2020).

„Wróż (gr. psychagogei) Sokrates wabi dusze...

I Peisandros tam w otusze

Biegnie ujrzeć ducha (gr. psyche) swego,

Co za życia umknął z niego (...)”. Arystofanes, Ptaki, tłum. z gr. J. Jedlicz, Warszawa 1954, 156 (1532-1543). 
silne emocje i doznania ${ }^{13}$. Ze względu na zanik praktyk duchowych w formie, w której uprawiano je w filozofii antycznej, metoda Sokratesa bywa błędnie postrzegana jako pewien rodzaj pracy wyłącznie intelektualnej. W utworach Platona Sokrates nie prowadzi rozmów o charakterze teoretycznym. Większość dialogów ma formułę terapeutyczną. Przedmiotem rozmowy jest to, co stanowi najważniejszy problem głównego rozmówcy Sokratesa (np. pobożność w przypadku Eutyfrona czy „nauczanie cnoty” w przypadku Protagorasa). Interpretacja metody sokratycznej w duchu psychologii homeryckiej odsłoniła jej skrywaną a następnie zapomnianą stronę ${ }^{14}$.

13 „(...) ze sobą jest dobrze, czasem za dobrze. I chyba trwam w stanie, bo wiele osób zauważyło blask. Co do ćwiczenia. Od początku mnie zaintrygowało. Gdzieś podskórnie czułam, że chyba to nie jest moment na to. Może obawa przed rozklejeniem się? A może dlatego, że nie wiedziałam, czy uda się dotrzeć do siebie? W trakcie poczułam kulkę w piersi i tak siedziała, nie bolało, nie cieszyło, ale było. Na podsumowaniu podzieliłam się tym i ponieważ nie puściłeś, to natychmiast weszłam w to. Już w momencie położenia ręki na piersi poczułam gorąco rozchodzące się wszędzie. W miarę jak rozmawialiśmy to uczucie przepływało, wracało i poczułam jakbym była bardzo daleko od Was, ale bardzo blisko siebie. Tak jak powiedziałam, poczułam dławiąca radość. Tak się czułam, gdy moja pierwsza córka się urodziła. Przy każdym kolejnym dziecku czułam się podobnie. To odczucie przy pierwszym dziecku było bogatsze o zaskoczenie. Po prostu tak jak w czasie ćwiczenia nie spodziewałam się tego. Temu wszystkiemu towarzyszyła niezwykła lekkość. Czułam jakbym się unosiła nad ziemią. Po wyjściu z budynku wsiadłam do samochodu i po prostu siedziałam kilkanaście minut, nie czułam, że mogę się skupić, żeby prowadzić samochód, byłam bardzo poruszona wewnętrznie. Trenuje w pracy, domu i ciekawie to wpływa na otoczenie - uspokaja”. „Nauczycielka” (2017).

„Podczas sesji (...) doświadczyłem dość mocnego przeżycia, które dało się odczuć na planie emocjonalnym, fizycznym i duchowym. Doświadczenie polegało na integracji części „energii”, która znajdowała się poza ciałem w obszarze kończyn dolnych. Po świadomym odczuciu owej energii nastąpił proces integracji, który wpłynął na bieżący stan mojej percepcji i odbioru otaczającej rzeczywistości. Poczułem sie bardziej kompletny i zharmonizowany niż na początku doświadczenia. Wyostrzeniu uległo postrzeganie kolorów i kształtów oraz poszerzeniu uległo pole widzenia, które stało się bardzo szerokie. We wnętrzu zagościł większy spokój, zrozumienie i akceptacja. Mogłem odczuć, że na poziomie energetycznym, coś się ułożyło i zharmonizowało. „Leśnik” (2020).

14 Platon zakładał, że pewne treści nauczania nie mogą być powszechnie dostępne. Por. T. Szlezak, Czytanie Platona, IFIS PAN, Warszawa 1997, 29. 
Platon definiuje „myślenie” jako rozmowę z własną dusząa ${ }^{15}$. Zgodnie z psychologią homerycką, aby doszło do tej rozmowy konieczne jest uobecnienie, któremu towarzyszy odczuwanie na poziomie ciała. Ktoś myśli, czuje, doznaje, jeśli dusze odpowiedzialne za te funkcje są uaktywnione w ciele. Jeśli warunek ten nie jest spełniony, to człowiek biernie przeżywa swoje akty myślowe, uczuciowe i cielesne. Arystotelesowski podział na umysł czynny i bierny ${ }^{16}$ bardzo dobrze oddaje specyfikę powyższego rozróżnienia ${ }^{17}$. U człowieka, który przyzwyczaił się do biernego działania, uaktywnienie stanu czynnego wymaga wysiłku i jest początkowo możliwe jedynie przez krótki czas. Rozmowa terapeutyczna polega na odblokowaniu „uśpionej” funkcji czynnej, dzięki kierowaniu uwagą i uaktywnieniu podążających za uwagą procesów duchowych. Aby zrozumieć samego siebie w dramacie swojego życia, by wznieść się myślą ku prawdzie, konieczne jest wsparcie Logosu poprzez uobecnienie siebie - mówiąc językiem starożytnych - konieczne jest świadome „przyjęcie ciała duchowego”, „narodzenie się ducha w ciele”. Jest to warunek konieczny

15 „Sokrates: Rozmowę (logon), którą dusza (psyche) sama z sobą prowadzi, cokolwiek weźmie pod uwagę. Objawiam ci to, chociaż sam dobrze nie wiem. Tylko tak mi się przedstawia dusza, kiedy rozmyśla, że niby rozmawia - sama sobie zadaje pytania i odpowiedzi daje, i mówi »tak«, i mówi »nie«. A kiedy granice pewne pociągnie - dusza czasem wolniej, czasem szybciej miarkuje - kiedy w końcu jedno i to samo powie (phemi), i już się nie waha, na obie strony, uważamy to za jej sąd. Zatem ja sądzeniem nazywam mówienie (logon), a sądem nazywam myśl (logos) tylko nie do kogoś innego, ani głosem (phone), tylko po cichu (sigao), do siebie samego. A ty jak?". Platon, Teajtet, w: Dialogi, tłum z gr. W. Witwicki, Kęty 1999, 2, 399-400/189 E-190 C/.

16 „W samej rzeczy istnieje [w niej] jeden rozum, który odpowiada materii - bo staje się wszystkim - i drugi [który odpowiada przyczynie sprawczej] - bo tworzy wszystko, jak specjalny rodzaj nawyku nabytego, podobny pod tym względem do światła, bo i światło na swój sposób sprawia, że barwy potencjalne stają się barwami aktualnymi. I ten rozum jest oddzielony, odporny na wpływy zewnętrzne i niezmieszany". Arystoteles, O duszy, 417b 3-28, 430a 14-23.

17 Proste ćwiczenie dobrze uzmysławia różnicę pomiędzy biernym i czynnym myśleniem. Odpowiedzmy na pytanie, ile jest: 2 x 2? A następnie na pytanie, ile jest: $234+313$ ? A teraz utrzymajmy swoim wysiłkiem stan aktywności wywołany czynnością myślową i starajmy się utrzymać go jak najdłużej. 
realnej przemiany jakościowej dokonującej się w ludzkiej psychice. Warunek niezbędny do otworzenia się na prawdę. Wagę tego aktu dobrze oddaje rozmowa Jezusa z Nikodemem. Drugi z wymienionych sprowadza znaczenie, padających w dialogu słów, do swojego biernego rozumienia ${ }^{18}$. Ewangelicznemu nauczaniu o wejściu do „Królestwa Bożego”, odpowiada w antycznej psychagogice pouczenie o tym, w jaki sposób człowiek może przechodzić od swojej jaźni-świadomości do swojej „na ogół nie znanej jaźni-nadświadomości” ${ }^{19}$. Filozofia i religia jednoczą się w tym miejscu w trosce o człowieka dążącego do osiągnięcia pełni życia.

\section{STAWANIE SIĘ OSOBĄ}

Terapia filozoficzna nie jest tylko interwencją w sytuacji kryzysowej. Kryzys jedynie ujawnia potrzeby człowieka i wymusza zmianę ${ }^{20}$. Po okresie pracy interwencyjnej rozpoczyna się stała praca nad przekształcaniem swojego bytu. Filozofia nie jest budowaniem systemu naukowego, „to raz powzięta decyzja, by prostodusznie spoglądać w siebie i wokół siebie"21. Nie chodzi o przekazanie oderwanej od życia nauki, a o duchowe przewodnictwo nakierowane na przekształcenie własnej duszy ${ }^{22}$. Nie jest to proces jednorazowy a „dzieło życia", w którym człowiek odkrywa swoją indywidualność - staje się osobą - dla siebie i dla innych. Dla stoików było to wiązanie uwagi (prosokhe) $\mathrm{z}$ ciałem, postawa duchowa przejawiająca się w ciągłej

18 „W odpowiedzi rzekł do niego Jezus: Zaprawdę, zaprawdę, powiadam ci, jeśli się ktoś nie narodzi powtórnie, nie może ujrzeć królestwo Bożego. Nikodem powiedział do Niego: Jakżeż może się człowiek narodzić będąc starcem? Czyż może powtórnie wejść do łona swej matki i narodzić się? Jezus odpowiedział: Zaprawdę, zaprawdę, powiadam ci, jeśli się ktoś nie narodzi z wody i z Ducha, nie może wejść do królestwa Bożego" (Jan 3:3-5), Biblia tysiąclecia, http://www.biblia-internetowa.pl/Jan/3/3.html (dostęp 21.2020).

19 A. Krokiewicz, Zarys Filozofii greckiej, Aletheia, Warszawa 2000, 280.

20 A. Mindell, O pracy ze śniącym ciałem, Pusty obłok, Warszawa 1991, 10.

21 P. Hadot, Filozofia jako ćwiczenie duchowe, tłum. z fr. P. Domański, Warszawa 2003, 10.

22 Tamże, 147. 
czujności, rozbudzonej samoświadomości oraz obecności i napięciu ducha. Dzięki takiemu nastawieniu wiedzieli oni, czego pragną i co w każdej chwili robią. Dzięki czujności ducha urzeczywistniana była podstawowa reguła ich życia - rozróżnienie między tym, co zależy i co nie zależy od człowieka ${ }^{23}$. Dzięki ćwiczeniom duchowym, wglądowi, medytacji, uważności uczy się człowiek stałego uczestnictwa pierwiastka duchowego w swoim życiu.

Stawanie się osobą to przede wszystkim odróżnianie „tego, co moje” od tego, „co nie moje” 24 . To odrzucanie przyjętych bezkrytycznie w procesie tzw. edukacji nawyków i wiedzy przysłaniającej prawdziwą mądrość. To stałe uwalnianie się od kulturowej „tresury” i pozwalanie sobie na bycie sobą - ujawnianie swoich potrzeb, pragnień zgodnych $z$ wewnętrzną naturą danej osoby. Jest to wyjście spod pręgierza mechanizmów obronnych trzymających człowieka w „niewoli” i powrót do własnej esencji.

Gdy proces pierwotny został uruchomiony i nastąpiła samoregulacja stanu klienta, rozpoczyna się praca nad aktywnym utrzymaniem wypracowanego, pożądanego stanu. Częścią procesu terapii filozoficznej jest pobudzanie klienta do zwracania uwagi na jego własne narracje wewnętrzne, nawyki myślowe i nawyki ruchowe. Celem jest tu podążanie za tym, co klient rozpoznaje jako swoje autentyczne wartości oraz zmniejszenie destrukcyjnego wpływu zachowań niepożądanych, przez wprowadzenie w ich miejsce nowych nawyków. Doznania, uczucia i myśli uruchomione podczas bycia w stanie pierwotnym, stają się punktem odniesienia i drogowskazem na drodze do dalszego rozwoju. Gdy stan ten zostanie utracony (zapomniany) zazwyczaj wracają traumy i nawyki myślowe, z którymi boryka się klient. Podczas kolejnego spotkania stan pierwotny jest ponownie

23 Tamże, 17.

24 W wypracowywaniu poczucia tożsamości osobowej pomocne może być odróżnianie myśli, które należą do nas, od myśli, które do nas nie należą. „Pierwsze cechuje ciepło i bliskość, których te drugie są całkowicie pozbawione”. W. James, Psychologia. Kurs skrócony, PWN, Warszawa 2002, 148. 
wywoływany i cały proces rozpoczyna się na nowo. Taka sytuacja powtarza się aż do momentu, w którym osoba utrwali pożądane zachowania. W tym okresie jest możliwa, a w przypadku niektórych klientów nawet wskazana, praca grupowa, podczas której wspólnie poddawane są analizie m.in. założenia i konsekwencje przyjmowanych przez klientów postaw życiowych, ich aktualny stosunek do przeżytej traumy, obrane cele. Osoby dzielą się swoimi obserwacjami, odkrytymi mechanizmami, trudnościami i sukcesami w poznawaniu siebie.

\section{ASPEKTY FILOZOFICZNE}

W utrwalaniu dobrostanu (utrzymywaniu własnego uobecnienia) wykorzystany może być wielowiekowy dorobek filozofii. Dobór i zastosowanie praktyk filozoficznych w dużej mierze zależy od filozofa terapeuty. Ma on jednak jedynie głos doradczy. Ostateczny wybór leży po stronie klienta, który sam decyduje o treści poruszanych problemów oraz wyborze proponowanych ćwiczeń.

Do podstawowych praktyk terapii filozoficznej należy sięganie do filozofii antycznej, która w pewnych obszarach znacznie lepiej niż współczesna psychologia, pozwala klientowi rozumieć jego własne stany psychiczne. Po zapoznaniu klienta z Platońskim trójpodziałem duszy, można zaproponować mu praktyczne ćwiczenia rozpoznawania funkcji psychicznych odpowiadających trójpodziałowi. Zazwyczaj wiąże się to $\mathrm{z}$ pytaniem o to, gdzie, w jakim obszarze ciała, klient utrzymuje uwagę (czy przeważa u niego bardziej percepcja głowy, klatki piersiowej, czy okolic brzucha). Wprowadzenie podziału na trzy części duszy ułatwia dalszą pracę nad nawykami ruchowymi, przyzwyczajeniami (np. „natrętnymi myślami” lub fantazjowaniem, day dreaming).

$\mathrm{Na}$ etapie początkowym przydatne mogą być ćwiczenia stoickie, np. „bycia obojętnym na rzeczy obojętne”, czy uwalnianie się od mechanizmu walki o „rację", chęci zwyciężania w rozmowach za wszelką 
cenę”, czy też „niewolnictwa słowa” (emocjonalnego i krytycznego odnoszenia do siebie znaczeń słów padających w rozmowach). Nie są to ćwiczenia obce współczesnym nurtom psychoterapii. Nie zmienia to faktu, że są one częścią antycznej praktyki filozoficznej, a ich celem, zarówno w starożytności jak i współcześnie, było i jest uwalnianie się od mechanizmów blokujących proces źródłowy (hamujących proces stawania się osobą). Stosując te ćwiczenia zakłada się, że człowiek jest ustrojem złożonym $\mathrm{z}$ nawykowych i nieuświadomionych przekonań oraz emocji i że jest on zdolny do autorefleksji, samopoznania oraz rozwoju duchowego, którego zakres przekracza wszelkie nasze wyobrażenia.

\section{TERAPIA FILOZOFICZNA I PODEJŚCIA ALTERNATYWNE}

Terapia filozoficzna w wielu miejscach stosuje środki typowe dla innych podejść: terapii narracyjnej, terapii zorientowanej na proces lub systemu wewnętrznej rodziny. Analiza wypowiedzi klienta na własny temat (konsekwencje, pochodzenie, kontekst) służy wytworzeniu nowej narracji ${ }^{25}$ o sobie. Pomaga to ludziom w odkrywaniu własnej tożsamości, odzyskaniu poczucia własnej wartości oraz w umiejętności życia w zgodzie ze sobą (harmonijnego) ${ }^{26}$.

Terapeuta filozoficzny może podążać za gestami, mikroruchami, wzmacniać sygnały towarzyszące analizowanym wypowiedziom, wyobrażeniom. Podobne zabiegi stosowane są np. w terapii zorientowanej na proces ${ }^{27}$. Tak jak terapia IFS (System Wewnętrznej Rodziny) uczy patrzenia na siebie z punktu widzenia wielości - tego,

25 „Narracja” to relacja z szeregu powiązanych wydarzeń lub doświadczeń. Może być w formie dziennika podróży, pamiętnika, autobiografii, biografi (realistycznej) lub bajki, historii, legendy, opowieści (fikcyjnej).

26 „Narracyjne mediacje to wysiłek stworzenia wizji przyszłości, opartej na wewnętrznej demokracji wspartej praktyką". J. Winslade, G.D. Monk, Practicing Narrative Mediation. Loosening the Grip of Conflict, Jossey-Bass, San Francisco 2008, 287.

27 A. Mindell, Śpiączka. Klucz do przebudzenia, Nuit Magique, Warszawa 1994, 12-14. 
że składamy się z części („kierowników, wygnańców i strażaków”) i że części te wchodzą w interakcję - tak filozof terapeuta uczy o trzech głównych składowych duszy człowieka i pomaga zintegrować ich działanie. Często towarzyszy temu wgląd do świata wewnętrznego klienta. W rozmowie klient może sięgać do archetypów, mitów czy postaci obecnych w jego świecie wewnętrznym ${ }^{28}$. Terapeuta filozoficzny może korzystać również z zachowań prowokatywnych (humoru, żartu, obśmiewania problemu w celu zdystansowania się do niego), typowych dla postawy cyników, ale w formie zbliżonej do tej, którą proponuje współcześnie terapia prowokatywna ${ }^{29}$.

28 „W trakcie warsztatów przyszło do mnie uczucie, które trudno jest mi opisać, niemniej było znajome. Było to poczucie czegoś ciężkiego w klatce piersiowej, przy jednoczesnym poczuciu, lub bardziej wyobrażenia kamienia, o czym opowiedziałem podczas podsumowania medytacji i wspólnego dzielenia się swoimi odczuciami. Prowadzący zaproponował, żebym przyjrzał się temu, co widzę, zacząłem więc podążać za jego pytaniami, oraz wskazówkami. Najpierw kamień był nie do ruszenia, to znaczy mogłem go tylko oglądać, ale nic więcej, nic mi nie mówił, ani niczego więcej nie widziałem. W końcu jednak znalazłem w nim przestrzeń, w którą mogłem wejść. Tak zrobiłem, a wchodząc do środka miałem wrażenie, że otwiera się dookoła mnie duża otwarta przestrzeń. Przestrzeń ta była jakby lasem pośrodku którego był staw, albo rzeka - na pewno była to woda. Znałem to miejsce, jakbym wcześniej był tam podczas swoich snów. Podszedłem do wody i ujrzałem na jej powierzchni kwiaty, zaś przed swoimi oczami ujrzałem symbol kwiatu, zdaje się, że lotosu. Zanurzyłem w niej ręce i obmyłem twarz. Pamiętam, że następnie udałem się do drzewa, które rosło obok i ujrzałem tam kobietę ubraną w biel i przyozdobioną kwiatami, która patrzyła na mnie. Nie pamiętam, czy powiedziała cokolwiek do mnie, czy tylko przyszło poczucie, niemniej poczułem, jakby wypełniła mnie energia matki, jakbym był mocno przytulony przez swoją mamę. Towarzyszyło temu uczucie rozpierającej siły, coś jakbym poczuł swoje ciało i urósł jednocześnie. Chciało mi się krzyczeć. Wtedy zacząłem czuć swoje fizyczne ciało, wstałem, ściągnąłem koszulkę i pamiętam uczucie wypełniającej siły, wewnętrznej energii, oraz poczucia swojego ciała fizycznego. Czułem siebie. Było to jedno z pierwszych moich poważnych „wejść” do świata wewnętrznego. Takie, w którym nie słyszałem za dużo słów, jednak odczucie, jakie we mnie wywołało, do dzisiaj na mnie oddziałuje. Od strony refleksji traktuje to jako spotkanie się ze źródłem i początkiem. Poczułem się, jakbym zszedł na sam dół samego siebie i zaczął jeszcze raz od nowa. Od tego czasu również poprawiły mi się kontakty z moją mamą, Częściej i chyba również szczerzej ją obejmuję.

29 F. Farrelly, J. Brandsma, Terapia prowokatywna, Metamorfoza, Wrocław 2004; N. Höfner, Styl prowokatywny w terapii i coachingu, GWP, Sopot 2017. 


\section{CEL TERAPII FILOZOFICZNEJ}

Podobnie jak inne podejścia, terapia filozoficzna oferuje klientom możliwość pracy nad zwiększeniem udziału świadomości w życiu i osiągnięciu większej wolności; wypracowaniem dystansu do swoich problemów i zmniejszeniem niepokojów ${ }^{30}$; odzyskaniem naturalnego dobrostanu psychicznego (eutymia) i uobecnienia.

Zakres pomocy oczywiście jest znacznie szerszy. Poniższa lista została sporządzona na podstawie tekstów antycznych. Do głównych celów stawianych w terapii filozoficznej należy „uobecnienie własnej duszy” oraz „rozmową z duszą” (uświadomione mówienie). Kolejne istotne cele to: osiąganie stanu umysłu wolnego od nieracjonalnych oczekiwań i tęsknot, oraz od autodestrukcyjnych wspomnień i żalu; skupianie uwagi na chwili obecnej; „,kierowanie wzroku duszy we właściwym kierunku" i przygotowanie duszy do przyjęcia prawdy o sobie. Ważne jest również życie zgodne $\mathrm{z}$ rozumem i nie wykluczające zwracania się do pozaracjonalnych składników duszy. Bycie przygotowanym na sytuacje niekomfortowe i umiejętność korzystania z życia, takiego jakie ono jest. Utrzymywanie umysłu w stanie elastycznej gotowości. Osiąganie takiej jakości życia, jaką pragnie się osiągnąć. Życie bez „problemu, że się żyje” tzn. osiągnięcie eudajmonii, naturalnego stanu codziennej egzystencji oczyszczonej z fałszywych problemów. Usuwanie tego, co zbędne w życiu (fałszywe sądy, urojone pragnienia, zła wola) i wyzbywanie się zaburzeń wywołanych przez te rzeczy (np. urojone pragnienia rodzące cierpienia). Odrywanie umysłu klienta od tego, co posiada i skierowanie jego uwagi na to, czym jest. Poszerzanie świadomości, poprzez przechodzenie od prostego utożsamienia się z jednostką fizyczną, do uświadomienia sobie, że jest się nie tylko częścią pewnego rodu, pewnego państwa, wspólnoty, lecz przede wszystkim częścią świata i pewnego porządku

30 L. Ostasz, O usprawnianiu rozumu i leczeniu psychiki. Psychoterapia filozoficzna, Laterna, Krynica Morska 2007, 14. 
ontologicznego, że jest się mikrokosmosem. Uzyskanie wewnętrznej harmonii.

Terapeuta filozoficzny podobnie jak psycholog, nie zajmuje się głębokimi zaburzeniami psychiatrycznymi. Może jednak wspomagać człowieka w sytuacji zagubienia orientacji życiowej, lekkiego bądź średniego poczucia wyobcowania w danej grupie społecznej, w przypadku osłabionego bądź utraconego poczucia sensu życia czy niepokoju związanego z wyborem drogi życiowej (niekiedy problemy te mogą wywołać myśli samobójcze u osób zdrowych psychicznie ${ }^{31}$; zniecierpliwieniu wobec czegoś lub kogoś, utracie zadowolenia czy subiektywnego poczucia szczęścia w życiu, plątaninie myśli, zamartwianiu się czy sztywności poglądów.

\section{STAWANIE SIĘ TERAPEUTĄ FILOZOFICZNYM}

Terapeuta filozoficzny jak każdy terapeuta powinien przejść własną terapię i posiadać odpowiednie umiejętności. W tym względzie terapeuta filozoficzny przechodzi ścieżkę rozwojową, która umożliwia mu późniejszą pracę z klientami. Dzięki praktyce zapoznaje się on $z$ antycznymi ćwiczeniami duchowymi, takimi jak: praktyki stoickie, uobecnienie siebie (majeutyka), życie zgodne z rozumem, utrzymanie umysłu w stanie gotowości, bycie przygotowanym na trudne sytuacje, przyjmowanie postawy otwartości na prawdę.

Terapeuta filozoficzny zna techniki ćwiczenia uwagi, różne techniki medytacyjne, sposoby opanowywania rozchwianych emocji, techniki samoobserwacji w działaniu, a w szczególności dialog Sokratejski oraz sposoby prowadzenia dyskusji. Jego szczególnie mocną stroną powinno być analizowanie pojęć i sposobów argumentacji, definiowanie tego, co nie zostało trafnie ujęte w rozmowie; nazywanie tego, co budziło emocje, było niemiłe bądź trudne, usuwanie barier intelektualnych. Prowadzenie rozmowy „celującej w porozumienie”,

31 Tamże, 173-174. 
znajomość technik znajdowania kompromisu; poruszania się w różnych systemach wartości a także umiejętność „zrywania z niektórymi praktykami społecznymi”. Specjalnością terapeuty filozoficznego powinno być podejmowanie pytań i problemów egzystencjalnych takich, jak kwestia istnienia Boga czy rozumienie pojęcia „Bóg”, a w przypadku klientów wierzących, umiejętność poruszania tematu sposobów „rozmawiania z Bogiem”.

\section{PRÓBA DEFINICJI}

Podanie zwięzłej a zarazem zupełnej definicji terapii filozoficznej jest trudne. Zacznijmy od definicji zawierającej błędne koło - „terapia filozoficzna jest tym, czym zajmuje się terapeuta filozoficzny”. Kieruje ona naszą uwagę na praktyczny aspekt definiowanego pojęcia. W tym aspekcie definiowane pojęcie to „zbiór czynności (oddziaływań) stosowanych przez filozofa terapeutę". W przypadku, gdy definiowana dyscyplina jest nowa, taka jej definicja może być jedyną możliwą. Zwrócił na to uwagę Thomas Kuhn w kontekście rozwoju nauki. Ze świadomością, że nasza definicja nie jest doskonała, możemy podjąć próbę definicji klasycznej, odróżniając terapię filozoficzną w zbiorze podejść terapeutycznych. Definicja taka mogłaby mieć wówczas następujący kształt: Filozof terapeuta to osoba posiadająca wiedzę i kompetencje niezbędne do pracy z drugim człowiekiem oraz stosująca antyczne metody filozoficzne. Co jest jednak istotą antycznych metod terapeutycznych? Jak to opisaliśmy wyżej, są to różne techniki uruchamiania zasobów duchowych, myślowych, uczuciowych i instynktownych człowieka, prowadzące do ujawnienia jego indywidualności (esencji), wyrażającej się w uobecnieniu siebie, byciu w harmonii ze sobą i otoczeniem, przejawiającym się w stanie eutymii ${ }^{32}$. Istotą tych technik jest to, że uruchamiają one proces, który

32 W zwięzłej formie definicja mogłaby mieć kształt następujący: Terapia filozoficzna jest to szereg czynności skoncentrowanych na poznawaniu oraz uruchamianiu zasobów 
można określić za Karlem Rogersem procesem „stawania się osobą”. Proces ten raz uruchomiony i świadomie podtrzymywany trwać może do końca życia człowieka. Impulsem do jego uruchomienia może być choroba, przeżyta trauma, wydarzenie losowe oraz (co istotne) naturalna wewnętrzna potrzeba rozwoju. Terapię filozoficzną w najszerszym sensie można zatem ująć jako „proces stawania się osobą" (w tym znaczeniu każdy jest własnym terapeutą filozoficznym). W wąskim sensie ujmujemy ją, jako wspierające uczestniczenie (towarzyszenie) terapeuty filozoficznego $\mathrm{w}$,procesie stawania się osobą" komuś, kto proces ten przeżywa (np. młodemu dorosłemu przechodzącemu kryzys rozwojowy) i stosuje m.in. antyczne, techniki filozoficzne (ćwiczenia duchowe).

Możliwe są oczywiście inne definicje, które będą wynikiem przyjmowanych przez terapeutę wartości, zasad, umiejętności oraz podstaw filozoficznych. Jedną z takich definicji zaproponował Piotr Leśniak w opisie konferencji Wokót idei doradztwa filozoficznego III. Terapia filozoficzna. Terapia filozoficzna jest według niego „forma krótkoterminowej terapii ukierunkowanej nie na diagnozę i leczenie zaburzeń psychicznych, lecz na uwalnianie potencjału i zasobów wewnętrznych klienta. Jest to nowoczesna forma terapii, bliska coachingowi, nawiązująca do tradycji dialogu filozoficznego. Kieruje klienta w stronę rozpoznania jego autentycznych wartości oraz rozumienia i adekwatnego wyrażania uczuć".

Ugruntowanie terapii filozoficznej, jako uznanej propozycji w szerokiej ofercie nurtów terapeutycznych, wymaga nie tylko opracowań naukowych i wnikliwych badań, lecz także większej liczby osób praktykujących filozofowanie w sensie antycznym, czyli filozoficzny sposób życia. Proces został zapoczątkowany i wierzymy, że z czasem

duchowych, myślowych, uczuciowych (emocjonalnych) i instynktowych człowieka, prowadzących do ujawnienia jego indywidualności (esencji), wyrażającej się w uobecnieniu siebie (byciu w harmonii ze sobą i otoczeniem) i przejawiającym się w stanie eutymii. 
zainteresowanie zarówno filozofią $\mathrm{w}$ rozumieniu antycznym jak i terapią filozoficzną będzie rosło.

\section{BIBLIOGRAFIA}

Arystofanes, Ptaki, tłum. z gr, J. Jedlicz, PIW, Warszawa 1954.

Arystoteles, O duszy, tłum. P. Siwek, http://mhl.elsat.net.pl/ARYSTOTELES\%20 \%20O\%20DUSZY.pdf (dostęp 21.03.2020).

Biblia tysiaclecia, http://www.biblia-internetowa.pl (dostęp 21.03.2020).

Biblia Apologety, http://bibliaapologety.com (dostęp 2.03.2020)

Biblia Oblubienica, pobrano z: https://biblia.oblubienica.eu (dostęp 2.03.2020).

Farrelly F., Brandsma J., Terapia prowokatywna, tłum. z ang., METAmorfoza, Wrocław 2004.

Femiak T., O uobecnieniu duszy, Sokratesie psychagogu i sztuce uświadomionego mówienia, Studia Philosophiae Christianae, 54(2018)3, 85-110.

Femiak T., Narodziny gtosu - sztuka uświadomionego mówienia, jako narzędzie rozpoznawania gtosu, w: Psychologia narracyjna. Tożsamośc, dialogowość, red. E. Dryll, Enetheia, A. Cierpka, Warszawa 2011, 43-62.

Hadot P., Filozofia jako íwiczenie duchowe, tłum. z fr. P. Domański, Aletheia, Warszawa 2003.

Höfner N., Styl prowokatywny w terapii i coachingu, tłum. z niem. I. Jurkiewicz-Buchała, GWP, Sopot 2017.

Homer, Iliada, tłum z gr. L. Siemieński, Zielona Sowa, Kraków 2004.

James W., Psychologia. Kurs skrócony, tłum. z ang. M. Zagrodzki, PWN, Warszawa 2002.

Kobierzycki T., Miejsce i rola uczuć w opisie duszy cielesnej i niecielesnej u Homera, Heksis (2010)4, 3-15.

Krokiewicz A., Zarys Filozofii greckiej, Aletheia, Warszawa 2000.

Lenartowicz, P., Koszteyn J., Dusza. Platońskie i arystotelesowskie pojęcie duszy, https://www.kul.pl/files/57/encyklopedia/lenartowicz_dusza.pdf (dostęp 21.03.2020).

Mindell A., O pracy ze śniqcym ciałem, tłum. z ang. M. Błasiak, Pusty obłok, Warszawa 1991.

Mindell A., Śpiaczka. Klucz do przebudzenia, tłum. z ang. T. Teodorczyk, Nuit Magique, Warszawa 1994.

Ostasz L., O usprawnianiu rozumu i leczeniu psychiki. Psychoterapia filozoficzna, Laterna, Krynica Morska 2007. 
Platon, Faidros, w: Dialogi, tłum. z gr. W. Witwicki, Antyk-Marek Derewiecki, Kęty 1999.

Platon, Teajtet, w: Dialogi, tłum z gr. W. Witwicki, Antyk-Marek Derewiecki, Kęty 1999.

Szlezak T., Czytanie Platona, IFIS PAN, Warszawa, 1997.

Winslade J., Monk G.D., Practicing Narrative Mediation. Loosening the Grip of Conflict, Jossey-Bass, San Francisco 2008.

Zieliński T., Psychologia homerycka, tłum. z ros. T. Kobierzycki, Heksis (1922/1999)1-2, 3-33.

\title{
THE BIRTH OF PHILOSOPHICAL THERAPY FROM THE SPIRIT OF ANTIQUITY. TOWARD BECOMING A PERSON
}

\begin{abstract}
This paper lists the problems that philosophical therapy deals with and tries to provide a definition of philosophical therapy. In particular, we find references to Homeric psychology, contemporary therapeutic trends, and examples of the use of philosophical therapy (observation records after individual sessions of philosophical therapy or group work). This article develops the connections between philosophical therapy and the ancient understanding of philosophy (ancient spiritual exercises). The focal point of our considerations concerns the application of philosophical therapy to the process of becoming a person.
\end{abstract}

Keywords: Becoming a person, philosophical therapy, practical philosophy, Homeric psychology, spiritual exercises, conscious speaking, self-presence, psyche

\section{TOMASZ FEMIAK}

tfemiak@gmail.com

Uniwersytet Opolski, Wydział Nauk Społecznych, Instytut Filozofii

ul. Strzelców Bytomskich 2, 45-084 Opole

ORCID: 0000-0002-5826-1102

DOI: 10.21697/spch.2020.56.2.04 